\title{
TREŚĆ I FORMA OPRACOWAŃ GRAFICZNYCH W MIEJSCOWYM PLANOWANIU PRZESTRZENNYM W KONTEKŚCIE ROZWOJU TECHNOLOGII GEOINFORMATYCZNYCH
}

\author{
THE CONTENT AND FORM OF GRAPHIC ARRANGEMENTS \\ IN LOCAL SPATIAL PLANNING IN THE CONTEXT \\ OF THE DEVELOPMENT OF GEO-INFORMATION TECHNOLOGIES
}

\begin{abstract}
NR DOI: $10.25167 / \mathrm{sm} 2018.032 .10 \quad$ s. $143-157$
ABSTRAKT: Planowanie przestrzenne dotyczy działań mających odwzorowanie w przestrzeni, dlatego nieodzowną częścią dokumentów planistycznych są opracowania graficzne. Ich treść i forma zmieniają się wraz ze zmianami przepisów prawnych oraz rozwojem technologii. W artykule autor przedstawia, jak zmieniały się rysunki planistyczne sporządzane w planowaniu miejscowym w okresie powojennym, oraz wskazuje, jak powinny być sporządzane obecnie, uwzględniając aktualne wymogi prawne oraz możliwości technologiczne.

SŁOWA KLUCZOWE: planowanie przestrzenne, rysunek planistyczny, GIS, INSPRE

ABSTRACT: Spatial planning concerns activities that have a mapping in space, therefore graphic design is an indispensable part of planning documents. Their content and form change along with the changes in legal regulations and the development of technology. In the article, the author presents how the planning drawings made in the local planning changed in the post-war period, and indicates how they should be prepared at present, taking into account the current legal requirements and technological possibilities.
\end{abstract}

KEY WORDS: spatial planning, planning drawing, GIS, INSPRE

\section{Wprowadzenie}

Polityka przestrzenna stanowi podstawowy element prowadzenia zintegrowanej polityki rozwoju ${ }^{1}$. Kluczowym instrumentem polityki przestrzennej jest planowanie zagospodarowania przestrzennego. W planowaniu tym poszukuje się najlepszych lokalizacji dla działań rozwojowych, określając dla nich warunki zagospodarowania terenowego na podstawie badań wszystkich związków, jakie zachodzą w przestrzeni

* Uniwersytet Opolski, Wydział Ekonomiczny, e-mail: joglecki@uni.opole.pl

1 http://www.mir.gov.pl/rozwoj_regionalny/Polityka_przestrzenna/Strony/polityka_przestrzenna.aspx. 
(Chmielewski 2001, s. 354, 357). Według definicji encyklopedii PWN planowanie przestrzenne to działalność zmierzająca do planowego zagospodarowania przestrze$n^{2}$. Działalność ta prowadzona jest przez władze publiczne na wszystkich szczeblach zarządzania. Krajowe i regionalne planowanie przestrzenne jest płaszczyzną, na której następuje konfrontacja i koordynacja resortowych planów i zamierzeń mających odwzorowanie w przestrzeni z koncepcją uporządkowanego rozwoju zagospodarowania przestrzennego państwa i regionów. Planowanie miejscowe prowadzone w gminach (miastach) jest procesem stanowienia przepisów definiujących sposób wykonywania prawa własności przez właścicieli lub użytkowników nieruchomości.

Ponieważ planowanie przestrzenne dotyczy działań mających odwzorowanie w przestrzeni, nieodzowną częścią dokumentów planistycznych z tego zakresu są opracowania graficzne przedstawiające lokalizację zamierzonych zadań rozwojowych. Szczególne znaczenie mają opracowania graficzne sporządzane $\mathrm{w}$ ramach planowania miejscowego, ze względu na jego cel i konsekwencje prawne. Treść i forma tych opracowań ulegają ustawicznym zmianom, wynikającym zarówno ze zmian przepisów prawnych określających zasady ich sporządzania, jak i z rozwoju narzędzi oraz technologii stosowanych w planowaniu przestrzennym. Celem niniejszego artykułu jest przedstawienie, jak zmieniały się treść i forma graficzna opracowań planistycznych w planowaniu miejscowym na tle uwarunkowań prawnych i możliwości technologicznych, oraz wskazanie aktualnych wymogów i potrzeb w tym zakresie, ze skoncentrowaniem na kwestiach przetwarzania i udostępniania dokumentów planistycznych. Materiał źródłowy do badań stanowiły dokumenty planistyczne sporządzone przez autora w okresie ostatnich 18 lat, udostępnione przez urzędy gmin województwa opolskiego poprzez usługi sieciowe WMS/WFS, oraz archiwalne z lat 1993-2000 udostępnione przez Biuro Projektowo-Konsultingowe BIPROK.

\section{Podstawowe zasady prawne planowania miejscowego}

Podstawę prawną planowania przestrzennego w Polsce stanowi obecnie ustawa z dnia 27 marca 2003 r. o planowaniu i zagospodarowaniu przestrzennym ${ }^{3}$. Planowaniu miejscowemu poświęcony jest rozdział 2 ustawy. Zgodnie z przepisami tego rozdziału na szczeblu gminnym sporządza się dwa podstawowe rodzaje dokumentów planistycznych: studium uwarunkowań i kierunków zagospodarowania przestrzennego gminy (studium gminne) oraz miejscowe plany zagospodarowania przestrzennego (plany miejscowe) (Ustawa z dnia 27 marca 2003 r. ..., art. 9 ust. 1, art. 14 ust. 1).

Studium sporządza się w celu określenia polityki przestrzennej gminy, w tym lokalnych zasad zagospodarowania przestrzennego. W dokumencie tym formułowane są cele i kierunki działań odnoszące się do wszystkich istotnych problemów wynikających ze strategii rozwoju lokalnego i różnych, w tym odległych, horyzontów czasowych. Cele

\footnotetext{
2 https://encyklopedia.pwn.pl/haslo/planowanie-przestrzenne;3957954.html.

3 Dz.U. z 2018 r., poz. 1945.
} 
te wiążą organy gminy i stanowią zobowiązanie do prowadzenia określonej polityki poprzez miejscowe plany zagospodarowania przestrzennego oraz inne działania wspomagające. Formalnie studium nie jest aktem prawa miejscowego. Zarówno w orzecznictwie sądowym, jak i w doktrynie przyjęło się określać je mianem aktu kierownictwa wewnętrznego czy też aktu gminnej polityki planistycznej. Oznacza to, że postanowienia studium mają charakter nienormatywny, są bowiem kierowane do organów gminy i bezpośrednio nie kształtują sytuacji prawnej podmiotów spoza systemu administracji publicznej (Bąkowski 2004, rozdz. 2, art. 9, pkt 1).

Zgodnie z przepisami przywołanej na wstępie ustawy studium powinno zawierać dwie zasadnicze kategorie treści: 1) część „informacyjną” - określającą uwarunkowania, stanowiącą swego rodzaju inwentaryzację dotychczasowego stanu faktycznego i prawnego obszaru, dla którego studium jest sporządzane, oraz diagnozę tego stanu; 2) część „regulacyjną” - określającą kierunki zagospodarowania przestrzennego gminy, konstytuującą dyspozycje gminnej realizacji polityki przestrzennej. Obligatoryjną częścią studium jest rysunek studium przedstawiający w formie graficznej ustalenia określające kierunki zagospodarowania przestrzennego gminy.

Miejscowy plan zagospodarowania przestrzennego, poprzez lokalne zasady, standardy i warunki kształtowania przestrzeni zawarte w jego ustaleniach, przenosi wyniki ustaleń studium na płaszczyznę decyzji regulujących zakres swobody kształtowania przestrzeni przez inwestorów i projektantów. Plan miejscowy jest jedynym dokumentem w systemie polskiego planowania przestrzennego mającym rangę aktu prawa miejscowego - uchwały rady gminy. Ta szczególna pozycja planu miejscowego w systemie planowania i jego prawny charakter jako przepisu lokalnego wyznaczają wymagania, jakie należy spełnić przy formułowaniu ustaleń planu, dotyczących zarówno treści, jak i formy zapisu. Miejscowy plan zagospodarowania przestrzennego sporządza się w celu ustalenia przeznaczenia terenów, w tym dla inwestycji celu publicznego, oraz określenia sposobów ich zagospodarowania i zabudowy. Ustalenia planu przedstawia się w formie tekstowej i graficznej. Ponieważ jest to akt prawa miejscowego, sporządza się go zgodnie z zasadami techniki prawodawczej, tj. część tekstowa planu stanowi treść uchwały, a rysunek planu - załącznik graficzny do uchwały. Rysunek planu razem z częścią tekstową tworzy uchwałę stanowiącą prawo i punkt wyjścia do dalszych działań rozwojowo-inwestycyjnych. Na rysunku planu określa się granice terenów o różnym przeznaczeniu wraz z symbolami przeznaczenia terenu oraz położenie wszystkich elementów zagospodarowania terenu objętych ustaleniami planu, mających odzwierciedlenie w przestrzeni (Ustawa z dnia 27 marca 2003 r. ..., art. 15 ust. 2, 3 i 4; Rozporządzenie Ministra Infrastruktury z dnia 26 sierpnia 2003 r. ..., $\mathbb{\$} 7$ ).

\section{Zasady prawne sporządzania opracowań graficznych w planowaniu miejscowym - rys historyczny}

Planowanie przestrzenne, jako główny instrument polityki przestrzennej, jest normowane przez przepisy prawne ukierunkowujące działalność planistyczną na realizację 
bieżących celów tej polityki. Zmiana polityki przestrzennej lub jej poszczególnych celów zawsze skutkuje zmianą przepisów regulujących problematykę planowania przestrzennego, stąd duża zmienność tych regulacji. Z punktu widzenia omawianego w niniejszym artykule zagadnienia najistotniejsze są zmiany przepisów określających zasady sporządzania dokumentów w planowaniu miejscowym, w tym szczególnie ich części graficznych.

W okresie powojennym, do czasu transformacji ustrojowej, obowiązywało w Polsce kilka aktów prawnych normalizujących planowanie przestrzenne, spośród których najistotniejszą rolę odegrały: dekret z dnia 2 kwietnia 1946 r. o planowym zagospodarowaniu przestrzennym kraju4, ustawa z dnia 31 stycznia 1961 r. o planowaniu przestrzennym $^{5}$ oraz ustawa z dnia 12 lipca 1984 r. o planowaniu przestrzennym ${ }^{6}$. We wszystkich wymienionych aktach prawnych mowa jest o planowaniu krajowym, regionalnym oraz o planowaniu miejscowym.

Zgodnie z dekretem z 1946 r. planowanie miejscowe obejmowało sporządzanie planów miejscowych dla poszczególnych osiedli istniejących i projektowanych bądź dla części osiedli, bądź dla kilku osiedli łącznie (art. 5 ust. 3). W dekrecie określony został zakres ustaleń planu miejscowego, bez sprecyzowania sposobu przedstawiania tych ustaleń w części tekstowej i graficznej (art. 5 ust. 2).

Ustawa z 1961 r. wprowadziła trzy rodzaje planów miejscowych: ogólne plany zagospodarowania przestrzennego jednostek osadniczych ${ }^{7}$, tzw. plany ogólne, plany zagospodarowania przestrzennego obszarów stanowiących zespoły jednostek osadniczych oraz szczegółowe plany zagospodarowania przestrzennego części jednostek osadniczych, tzw. plany szczegółowe. Plan ogólny miał określać w sposób wszechstronny podstawowe kierunki i skalę rozwoju oraz zasady zagospodarowania przestrzennego terenu na okres planu, jak również program i sposób zagospodarowania przestrzennego jednostki osadniczej w okresie najbliższego wieloletniego narodowego planu gospodarczego (art. 13 ust. 1). Plan szczegółowy miał natomiast określać szczegółowo przeznaczenie terenów na poszczególne cele, wyznaczać linie rozgraniczające te tereny, ustalać zasady uzbrojenia i urządzenia terenu, określać linię oraz dopuszczalną wysokość zabudowy, a w miarę potrzeby również inne warunki i wytyczne kształtowania zabudowy (art. 16 ust. 3).

Na podstawie delegacji zawartej w wymienionej ustawie (art. 27) wydane zostało zarządzenie nr 27 Ministra Budownictwa i Przemysłu Materiałów Budowlanych z dnia 3 września 1968 r. w sprawie szczegółowych przepisów o sporządzaniu miejscowych planów zagospodarowania przestrzennego („Dziennik Budownictwa” nr 12, poz. 62),

4 Dz.U. z 1946 r. Nr 16, poz. 109.

5 Dz.U. z 1975 r. Nr 11, poz. 67 z późn. zm.

6 Dz.U. z 1989 r. Nr 17, poz. 99 z późn. zm.

7 W rozumieniu ustawy jednostka osadnicza to „miasto, wieś lub inna miejscowość, która stanowi skupienie budynków mieszkalnych i wraz powiązanymi z nimi urządzeniami produkcyjnymi i usługowymi tworzy określone środowisko życia ludności”. 
z załącznikiem „Zestawienie ujednoliconych oznaczeń w rysunku planu” normującym sposób graficznego zapisu ustaleń planów miejscowych. Zestawienie obejmuje pełny zakres oznaczeń graficznych stosowanych w planowaniu miejscowym, zróżnicowanych ze względu na skalę (uwzględniono pięć skal - od 1:25 000 do 1:1000). Łącznie określono 147 rodzajów oznaczeń, w tym 37 oznaczeń ogólnych (różnego rodzaju granice, linie regulacyjne, elementy zagospodarowania do zachowania i kształtowania i inne) oraz 110 oznaczeń przeznaczenia terenów i obiektów w podziale funkcjonalnym (przemysł, składy i budownictwo, rolnictwo i leśnictwo, mieszkalnictwo, administracja i usługi, zieleń, komunikacja i transport, regulacja stosunków wodnych, odprowadzenie ścieków i usuwanie nieczystości, inne przeznaczenie terenu). Przeznaczenia terenów oznaczone zostały za pomocą koloru i symbolu literowego, pozostałe elementy rysunku planu za pomocą różnego rodzaju oznaczeń graficznych liniowych, punktowych oraz liter i cyfr.

W okresie obowiązywania ustawy z 1961 r. wydany został jeszcze jeden normatyw oznaczeń graficznych przeznaczony do stosowania w planach przestrzennego zagospodarowania gmin, który implementuje wcześniej wydane oznaczenia - Wytyczne do opracowania planów przestrzennego zagospodarowania gmin - załącznik 2 „Ujednolicone oznaczenia w planach miejscowych” (wyd. Ministerstwo Administracji, Gospodarki Terenowej i Ochrony Środowiska - Ministerstwo Rolnictwa, Warszawa, sierpień 1978).

Kolejna ustawa, z 1984 r., nie wniosła zmian w zakresie rodzajów dokumentów planistycznych w planowaniu miejscowym. Praktycznie nie wprowadziła też zmian w zakresie sporządzania rysunków planów miejscowych; formalnie w wydanym na mocy tej ustawy zarządzeniu Ministra Gospodarki Przestrzennej i Budownictwa z dnia 17 października 1988 r. w sprawie zasad sporządzania projektów założeń do miejscowych planów zagospodarowania przestrzennego uchylone zostało zarządzenie nr 27 z dnia 3 września 1968 r. w sprawie szczegółowych przepisów o sporządzaniu miejscowych planów zagospodarowania przestrzennego, ale ponieważ nie wydano nowych norm sporządzania rysunków planów miejscowych, rysunki te wykonywane były w dotychczasowy sposób.

Proces transformacji ustrojowej państwa przyniósł nowe uregulowania problematyki zagospodarowania przestrzennego. Podstawowym nowym dokumentem w tym zakresie była ustawa z dnia 7 lipca 1994 r. o zagospodarowaniu przestrzennym ${ }^{8}$, która weszła w życie z dniem 1 stycznia 1995 r. Ustawa zasadniczo zmieniła cały dotychczasowy system planowania przestrzennego, w tym system aktów planowania przestrzennego. Na poziomie planowania miejscowego dotychczasowe miejscowe plany ogólne i szczegółowe zostały zastąpione przez miejscowe plany zagospodarowania przestrzennego (bez podziału na ogólne i szczegółowe) o randze aktów prawa miejscowego, tzw. plany miejscowe, oraz gminne studia uwarunkowań i kierunków zagospodarowania przestrzennego, niemające charakteru normatywnego, tzw. studia gminne. Ustawa

8 Dz.U. Nr 89, poz. 415. 
nie określiła żadnych reguł sporządzania graficznych dokumentów planistycznych. W przypadku rysunków planów stosowane były więc zwyczajowo dotychczasowe normy, natomiast rysunki studiów, niemających żadnych odpowiedników w przeszłości, wykonywane były zupełnie dowolnie.

\section{Aktualne zasady prawne sporządzania opracowań graficznych w planowaniu miejscowym}

Z dniem 11 lipca 2003 r. ustawę o zagospodarowaniu przestrzennym zastąpiła w całości ustawa z dnia 27 marca 2003 r. o planowaniu i zagospodarowaniu przestrzennym, obowiązująca do chwili obecnej. Najistotniejszą zmianą związaną z omawianą problematyką było wprowadzenie na mocy tej ustawy aktów wykonawczych określających zasady sporządzania planów miejscowych i studiów gminnych, tj. rozporządzenia Ministra Infrastruktury z dnia 26 sierpnia 2003 r. w sprawie wymaganego zakresu projektu miejscowego planu zagospodarowania przestrzennego oraz rozporządzenia Ministra Infrastruktury z dnia 28 kwietnia 2004 r. w sprawie zakresu projektu studium uwarunkowań i kierunków zagospodarowania przestrzennego gminy ${ }^{9}$.

W rozporządzeniach określono dość ogólnikowo wymaganą zawartość rysunków planistycznych, tj. rysunku planu i rysunku studium. W pierwszym z nich określono także (w formie załącznika) podstawowe barwne oznaczenia graficzne i literowe dotyczące przeznaczenia terenów, które należy stosować na projekcie rysunku planu miejscowego. Oznaczenia obejmują 28 rodzajów przeznaczenia terenu w podziale na tereny: zabudowy mieszkaniowej, zabudowy usługowej, zabudowy techniczno-produkcyjnej, użytkowane rolniczo, zabudowy techniczno-produkcyjnej, zieleni i wód, komunikacji, infrastruktury technicznej. W zakresie oznaczeń graficznych dotyczących granic i linii regulacyjnych oraz elementów zagospodarowania przestrzennego przepisy rozporządzenia odsyłają do Polskiej Normy PN-B-01027 z dnia 11 lipca 2002 r. - „Rysunek budowlany. Oznaczenia graficzne stosowane w projektach zagospodarowania działki lub terenu”. Z praktycznego punktu widzenia regulacje te są dalece niewystraczające; oznaczenia przeznaczenia terenu obejmują tylko przeznaczenia podstawowe, są więc niekompletne (por. „Zestawienie ujednoliconych oznaczeń w rysunku planu” z 1968 r.), natomiast oznaczenia określone w przywołanej w rozporządzeniu normie nie są dostosowane do rysunku planu, zarówno w zakresie przedmiotu oznaczeń, jak i w zakresie skali. Prawodawca, mając najprawdopodobniej tego świadomość, dopuścił stosowanie na projekcie rysunku planu miejscowego „uzupełniających i mieszanych oznaczeń barwnych i jednobarwnych oraz literowych i cyfrowych, w zależności od specyfiki i zakresu ustaleń dotyczących przeznaczenia terenów oraz granic i linii regulacyjnych" (\$ 9 pkt 1). W efekcie znaczna część oznaczeń na rysunkach planów to oznaczenia fakultatywne, tworzone przez projektantów.

\footnotetext{
9 Dz.U. z 2004 r. Nr 118, poz. 1233.
} 
W rozporządzeniu dotyczącym zakresu studium gminnego problematykę stosowania oznaczeń na rysunku studium reguluje tylko jeden przepis, który brzmi: „barwne oznaczenia graficzne i literowe, a także symbole i nazewnictwo na rysunku projektu studium należy stosować w sposób umożliwiający porównanie ustaleń studium uwarunkowań i kierunków zagospodarowania przestrzennego gminy z projektami planów miejscowych, sporządzanych z ustaleniami studium” (\$ 7 pkt 4). W efekcie rysunki studiów wykonywane są dalej zupełnie dowolnie.

\section{Rozwój narzędzi i technologii stosowanych $\mathrm{w}$ planowaniu przestrzennym}

Forma graficznych części dokumentów planistycznych w ostatnich latach zmieniała się i ewoluowała tak, jak rozwijały się dostępne narzędzia ułatwiające i wspomagające pracę urbanistów.

Zanim do powszechnego użycia trafiły komputery klasy PC wyposażone w różnego rodzaju programy graficzne, rysunki planów miejscowych sporządzano odręcznie w oparciu o fotokopie podkładów map topograficznych lub zasadniczych (odpowiednio do skali planu). Wykonywano je dwuetapowo - najpierw powstawały matryce, tj. rysunki czarno-białe wykreślane na folii kreślarskiej, a następnie ozalidowe kopie tych rysunków były malowane farbami. Tego typu opracowania charakteryzowały się ogromną pracochłonnością, brakiem możliwości wprowadzania zmian oraz mniejszą precyzją i szczegółowością. Nie było też możliwości powielania kolorowych rysunków planów.

Pierwsze opracowania sporządzane na komputerze były w zasadzie powieleniem schematów i oznaczeń wykonywanych odręcznie, komputer był jedynie bardziej zaawansowanym narzędziem rysunkowym i jedyne „wspomaganie”, jakie oferował, to możliwość łatwego powielania i kopiowania utworzonego rysunku oraz swobodnego wprowadzania zmian i korekt. Rysunki takie były opracowywane w oparciu o mapy rastrowe tworzone poprzez skanowanie map analogowych (papierowych lub foliowych), których dokładność zazwyczaj pozostawia wiele do życzenia.

Kolejnym etapem w rozwoju technologii sporządzania rysunku planistycznego było zastosowanie programów środowiska CAD. Programy te zasadniczo nie są narzędziem stworzonym na potrzeby planowania przestrzennego, jest to narzędzie wspierające inżynierów przy tworzeniu dokumentacji projektowej architektonicznej, budowlanej, maszynowej i in. Jednakże szereg oferowanych przez nie precyzyjnych funkcji rysunkowych i edycyjnych spowodował, że znajdują one szerokie zastosowanie również w opracowywaniu rysunków planu miejscowego i studium gminnego. Do ich sporządzania nadal wykorzystuje się skany map analogowych, tj. mapy rastrowe, a w ostatnim okresie także coraz częściej dostępne ich cyfrowe „cadowskie” wersje. Cyfrowe wersje map, w szczególności te opracowane przez geodetów od podstaw w środowisku CAD, dają możliwość bardzo precyzyjnego rysowania, włączania i wyłączania poszczególnych treści mapy. 
Obecnie najbardziej zaawansowaną technologią wspomagającą przygotowywanie załączników graficznych w planowaniu przestrzennym jest szeroko pojęte środowisko GIS. Pracując w GIS-ie, wykorzystuje się oraz tworzy dane przestrzenne. Oprócz grafiki tworzone są metadane, czyli dane o danych, informacje o strukturze, miejscu przechowywania i innych cechach zbiorów danych ${ }^{10}$. W odróżnieniu od wszystkich wyżej przedstawionych metod opracowanie planistyczne sporządzone w GIS-ie to nie tylko rysunek (załącznik graficzny), ale także zbiór danych (informacji) przestrzennych, opisujących szczegółowo wszystkie zagadnienia planistyczne na opracowywanym obszarze, zarówno w postaci graficznej, jak i opisowej. Narzędzia GIS dają możliwość korzystania zarówno z map rastrowych, jak i z map cyfrowych; zarówno jedne, jak i drugie mają nadawane georeferencje, co skutkuje tym, że po odpowiednim skalibrowaniu podkładu mapowego dodawanie kolejnych danych przestrzennych jest automatycznie osadzane w odpowiednim miejscu w przestrzeni geograficznej i wszystkie informacje w opracowaniu są prawidłowo zlokalizowane.

\section{Podstawowe informacje o GIS}

GIS to Geographical Information Systems, co w wiernym tłumaczeniu na język polski oznacza System Informacji Geograficznej (SIG), stosuje się także określenie System Informacji Przestrzennej (SIP).

W praktyce idea GIS polega na przetwarzaniu danych przestrzennych (mapy, zdjęcia satelitarne i lotnicze, plany itp.) w powiązaniu z informacjami pochodzącymi z baz danych, a mającymi jakiś komponent geograficzny (np. współrzędne geograficzne, numer działki, adres). Według definicji przyjętej przez W. Izdebskiego „systemem informacji geograficznej nazywa się system pozyskiwania, przetwarzania, weryfikowania, integrowania, manipulowania, analizowania i prezentacji danych, które są przestrzennie odniesione do Ziemi. Obejmuje on zazwyczaj bazę danych przestrzennych oraz odpowiednie oprogramowanie" (Izdebski 2009, s. 8). Jak wynika z tej definicji, elementami systemu informacji przestrzennej są baza danych oraz specjalistyczne oprogramowanie wraz ze sprzętem i ludźmi go obsługującymi. Baza danych zawiera informacje przestrzenne (graficzne) i opisowe o obiektach istniejących w świecie rzeczywistym reprezentowanych w systemie. Jest ona podstawą funkcjonowania systemu informacji przestrzennej. Dane zgromadzone w bazie, tzw. atrybuty, opisują cechy poszczególnych obiektów. Atrybuty, ze względu na rodzaj przechowywanej w nich informacji, dzielą się na:

- przestrzenne - określające położenie, wielkość i geometryczny kształt obiektów oraz ich przestrzenne (topologiczne) relacje;

- opisowe - określające nieprzestrzenne właściwości i relacje obiektów.

Oprogramowanie jest niezbędne do tworzenia bazy danych i wykonywania złożonych operacji systemowych. Obecnie na rynku jest dostępnych wiele programów GIS,

\footnotetext{
10 https://sjp.pl/metadane
} 
różniących się zarówno zastosowanymi rozwiązaniami, jak i zakresem oferowanych funkcji. Wszystkie posiadają jednak pewną stałą grupę funkcji charakterystycznych dla tego typu oprogramowania. Ogólnie funkcje oferowane przez oprogramowanie systemu informacji przestrzennej możemy podzielić na cztery zasadnicze grupy: 1) wprowadzanie danych; 2) zarządzanie danymi; 3) przetwarzanie danych; 4) udostępnianie danych (Izdebski 2009, s. 8). GIS, ze względu na swoje funkcje, znajduje coraz szersze zastosowanie w wielu obszarach działania, w tym w planowaniu przestrzennym.

\section{Wymogi w zakresie treści i formy rysunków planistycznych wynikające $\mathrm{z}$ ich funkcji}

Zgodnie z przedstawionymi wyżej zasadami miejscowego planowania przestrzennego na poziomie gminy sporządza się dwa dokumenty planistyczne: studium uwarunkowań i kierunków zagospodarowania przestrzennego gminy (studium gminne) oraz miejscowy plan zagospodarowania przestrzennego (plan miejscowy). Obligatoryjną częścią studium gminnego jest rysunek studium, a planu miejscowego - rysunek planu. $\mathrm{Na}$ rysunkach tych przedstawia się wszystkie ustalenia dokumentów planistycznych, które mają odzwierciedlenie w przestrzeni. Rysunki planistyczne są zatem wizualną formą przekazu informacji zawartych w dokumentach planistycznych. Ze względu na tę funkcję powinny być one czytelne i zrozumiałe dla odbiorcy oraz dokładne (precyzyjne). To ostatnie dotyczy w szczególności rysunku planu miejscowego, który jest graficzną częścią aktu prawnego definiującego sposób wykonywania prawa własności przez właścicieli lub użytkowników nieruchomości.

\section{Udostępnianie dokumentów planistycznych}

Adresatem dokumentów planistycznych jest szeroki krąg interesariuszy: właścicieli poszczególnych nieruchomości, zainteresowanych osiedleniem się lub prowadzeniem działalności gospodarczej na danym terenie, podmiotów publicznych powiązanych $\mathrm{z}$ tym terenem. $\mathrm{Z}$ tego względu dokumenty te muszą być powszechnie dostępne.

W ostatnich latach obowiązek udostępnienia gminnych aktów planistycznych nałożony został na gminy. Wynika on z dyrektywy 2007/2/WE Parlamentu Europejskiego i Rady z dnia 14 marca 2007 r. ustanawiającej infrastrukturę informacji przestrzennej we Wspólnocie Europejskiej (INSPIRE) oraz jej transpozycji na polskie prawodawstwo w postaci ustawy z dnia 4 marca 2010 r. o infrastrukturze informacji przestrzennej (Dz.U. z 2010 r. Nr 76, poz. 489 z późn. zm.). Wymienione akty prawne wprowadziły obowiązek informatyzacji zbiorów danych przestrzennych, do których zgodnie z załącznikiem do ustawy należy również zagospodarowanie przestrzenne. Obecnie większość polskich miast i gmin posiada już internetowe portale mapowe (Izdebski, Malinowski 2017, s. 77). W wielu z nich znajdują się warstwy tematyczne zawierające miejscowe plany zagospodarowania przestrzennego oraz studia uwarunkowań i kierunków zagospodarowania przestrzennego gmin. Zgodnie z oczekiwaniami warstwy 
te powinny znajdować się na wszystkich portalach mapowych. Aby to osiągnąć, konieczne jest wykonanie pracy związanej z przekształceniem istniejących dokumentów planistycznych do postaci cyfrowej oraz wdrażanie wymagań w zakresie nowych opracowań planistycznych. Wdrażanie wymagań technicznych (format, zestaw i zawartość atrybutów, odniesienie do tekstu uchwały) pozwoli na zminimalizowanie powtórnego przetwarzania dokumentów planistycznych do postaci bazy danych GIS (Izdebski, Malinowski 2017, s. 77). Obecnie portale mapowe tworzone są przez firmy komercyjne zajmujące się oprogramowaniem z zakresu systemów informacji przestrzennej (np. Geo-System Sp. z o.o., GISON Sp. z o.o.), które stosują własne (autorskie) schematy służące do publikacji danych przestrzennych. W efekcie możliwości i sposoby korzystania z tych portali są bardzo różne. Z punktu widzenia użytkowego pożądane byłoby unormowanie (standaryzacja) schematu służącego do publikacji dokumentów planistycznych. Standaryzacja taka uprościłaby dostęp do tych dokumentów i poszczególnych informacji w nich zawartych, a także dałaby spójność danych przestrzennych i ułatwiła korzystanie z wszystkich dodatkowych funkcji GIS.

Obowiązek informatyzacji zbiorów danych przestrzennych jest jedną z głównych przesłanek stosowania narzędzi GIS w planowaniu przestrzennym, ale nie jedyną.

\section{Zastosowanie narzędzi GIS przy opracowywaniu rysunków planistycznych - zalety, możliwości, problemy}

Zastosowanie narzędzi GIS (oprogramowanie i dane geograficzne) przy opracowywaniu rysunków planistycznych oferuje wszystkie udogodnienia znane z pracy w środowisku CAD oraz szereg nowych możliwości charakterystycznych i możliwych tylko dla GIS. Udogodnienia te to:

- praca w określonym globalnym układzie współrzędnych, co daje możliwość łatwego i precyzyjnego dodawania nowych danych przestrzennych;

- swobodne korzystanie z coraz szerzej dostępnych danych geograficznych, ilustrujących zagadnienia przestrzenne z różnych dziedzin;

- możliwość dodawania do elementów graficznych, takich jak poligony, linie, punkty, dodatkowych informacji opisowych, numerycznych, zgodnych z częścią tekstową dokumentu planistycznego;

- możliwość integracji rysunku z częścią tekstową;

- możliwość szybkiej weryfikacji opracowania z ogólnodostępnymi zbiorami danych;

- możliwość wykonywania analiz przestrzennych korzystających zarówno z możliwości badania wzajemnych relacji przestrzennych wszystkich elementów graficznych znajdujących się w opracowaniu, jak i z możliwości badania elementów opisowych i numerycznych towarzyszących wszystkim elementom graficznym;

- możliwość udostępniania dowolnych elementów i części składowych rysunków planistycznych wynikająca z kompatybilności rysunków opracowanych w GIS z geoportalami;

- automatyczne skalowanie wyświetlanej treści (ryc. 1). 


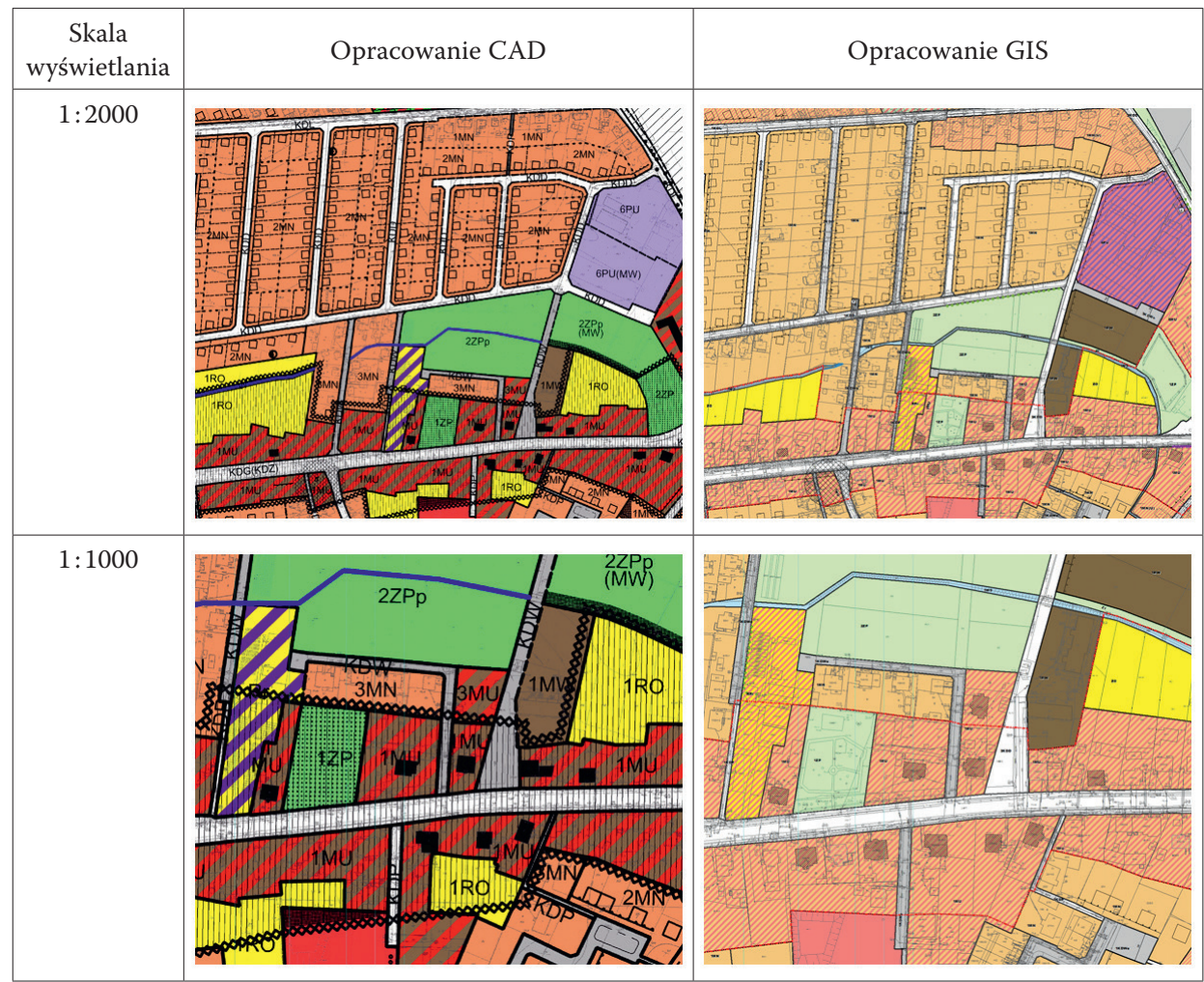

Ryc. 1. Różnice w sposobie symbolizacji informacji graficznych opracowania CAD i GIS. Aplikacje GIS (ArcMap) automatycznie dopasowują symbolizację do zadanej skali wyświetlania

Źródło: opracowanie własne.

Pozornie rysunek planistyczny wykonany za pomocą programu GIS, czyli część graficzna dokumentu planistycznego, jest podobny do rysunków wykonanych ręcznie czy w programach CAD. Jest to rysunek-mapa, który możemy wydrukować w dowolnej skali, udostępnić $\mathrm{w}$ formie obrazu rastrowego $\mathrm{w}$ formatach: JPG, TIFF, PDF. Natomiast faktycznie, w odróżnieniu do opracowań odręcznych i tych tylko „rysowanych” na komputerze, rysunek utworzony w środowisku GIS oferuje dodatkowo geobazę danych geograficznych, zbiór atrybutów i informacji o wszystkim tym, co znajduje się na rysunku (ryc. 2).

W kontekście planowania miast szczególną uwagę warto zwrócić na możliwości wykonywania analiz przestrzennych, jakie daje środowisko GIS. Miasto jest bowiem strukturą przestrzenną szczególnie złożoną i zmienną. Elementami tej struktury są tereny o odmiennym użytkowaniu, powstające dwojako: w planowanym procesie desygnacji przeznaczenia oraz spontanicznie urządzane. Obie formy zagospodarowania nie zawsze znajdują pełną akceptację wśród użytkowników, co skutkuje zmianami, modyfikacjami i uzupełnieniami (Kaczmarek 2012, s. 10). 

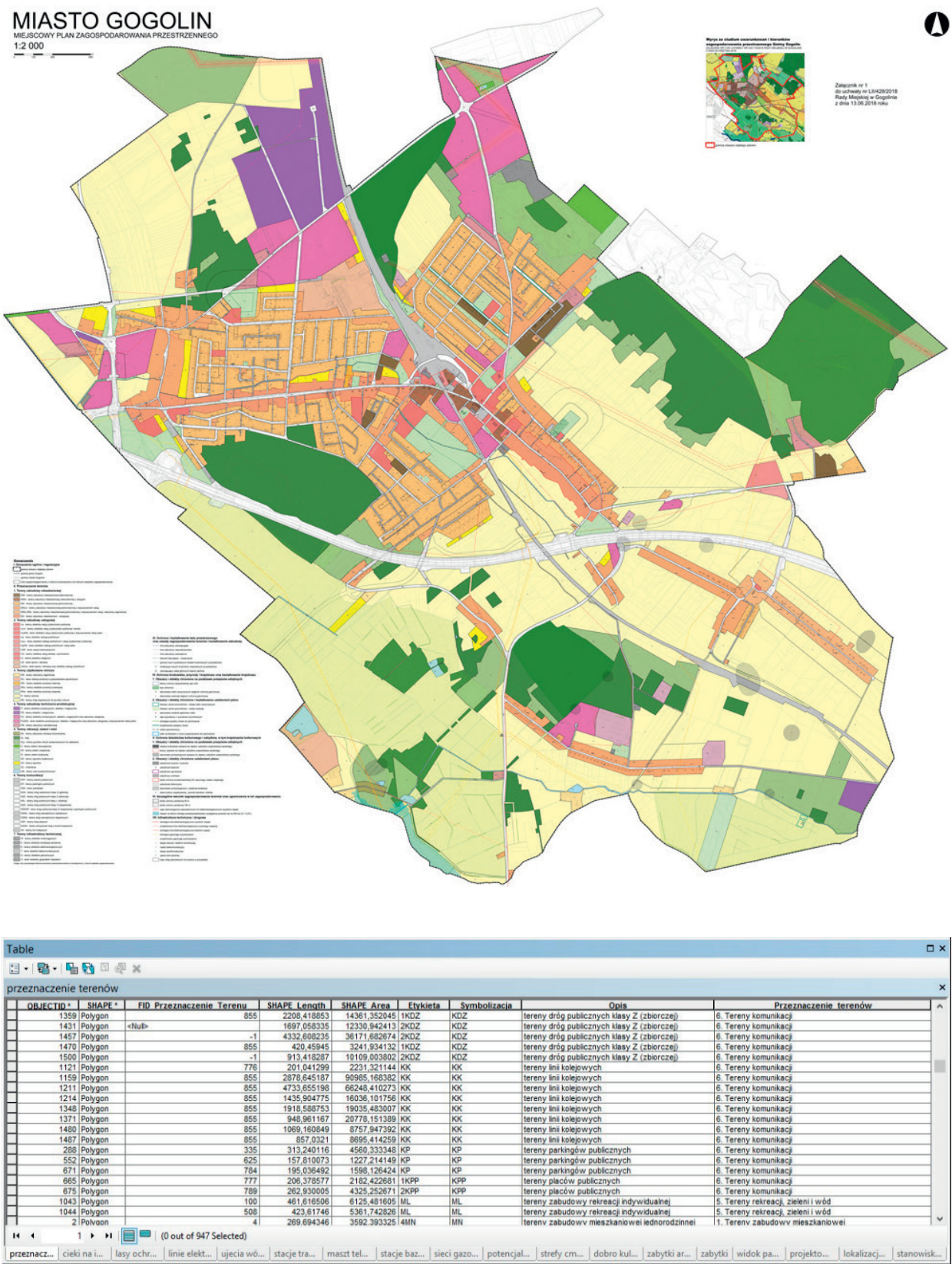

Ryc. 2. Rysunek miejscowego planu zagospodarowania przestrzennego wykonanego w programie GIS z fragmentem tabeli atrybutów dla warstwy przeznaczenia terenu Źródło: opracowanie własne. 
Zalety rysunków planistycznych wykonanych w programie GIS obrazuje tabela 1.

Tabela 1

Zestawienie możliwości technicznych rysunków planistycznych ze względu na technikę wykonania

\begin{tabular}{|l|c|c|c|}
\hline \multicolumn{1}{|c|}{ Technika wykonania } & $\begin{array}{c}\text { Opracowanie } \\
\text { manualne }\end{array}$ & $\begin{array}{c}\text { Opracowanie } \\
\text { CAD }\end{array}$ & $\begin{array}{c}\text { Opracowanie } \\
\text { GIS }\end{array}$ \\
\hline Publikacja w formie papierowej & tak & tak & tak \\
Publikacja w formie cyfrowej & - & tak & tak \\
Publikacja w formie bazy danych informacji prze- & - & - & tak \\
strzennych & - & tak & tak \\
Możliwość edycji i wprowadzania zmian & tak & tak & tak \\
Możliwość wykorzystania map rastrowych & - & tak & tak \\
Możliwość wykorzystania map cyfrowych & - & - & tak \\
Możliwość wykorzystania zewnętrznych metadanych & - & tak \\
Automatyczne skalowanie wyświetlanej treści & tak & tak & tak \\
Załącznik graficzny do uchwały & tak & tak & tak \\
Zawartość informacji graficznych & - & - & tak \\
Możliwość pracy na warstwach tematycznych & & & \\
Tworzenie atrybutów opisowych do danych graficznych & - & & tak
\end{tabular}

Źródło: opracowanie własne.

Przy pracy w środowisku GIS poza wieloma udogodnieniami napotykamy też na problemy. Wynikają one z braku spójności udostępnianych danych geograficznych, ich często niskiej jakości, a także z braku wielu danych. Na taki stan rzeczy składa się kilka czynników. Przede wszystkim proces informatyzacji zbiorów danych przestrzennych jest w Polsce wciąż w fazie rozwoju. Brak też normalizacji (standaryzacji) mechanizmów i schematów tworzenia danych przestrzennych wykorzystywanych i stosowanych w planowaniu przestrzennym. GIS z założenia służy płynnej integracji różnego rodzaju danych przestrzennych. W myśl tego założenia tworzenie danych przestrzennych związanych z zagospodarowaniem przestrzennym powinno podlegać zintegrowanym zasadom, zarówno w zakresie symbolizacji, jak i struktury tworzonych danych.

Innym problemem, na który warto w tym miejscu zwrócić uwagę, jest brak standaryzacji oznaczeń graficznych na rysunkach planistycznych. Jej wprowadzenie pozwoliłoby na szersze wykorzystywanie możliwości systemu GIS, a także na rozbudowanie w programach komputerowych funkcji wspomagających wykonywanie rysunków planistycznych. Rysunki planistyczne z jednakowymi oznaczeniami byłyby też łatwiejsze w odbiorze, co z racji ich funkcji jest również bardzo ważne.

Katalogi (zestawienia) ujednoliconych oznaczeń na rysunkach planistycznych powinny zostać opracowane przez zespół specjalistów z zakresu urbanistyki i planowania 
przestrzennego, gospodarki przestrzennej, informatyki, i powinny być obowiązującym standardem dla opracowań planistycznych.

\section{Podsumowanie i wnioski}

Obligatoryjnymi elementami dokumentów planistycznych w planowaniu miejscowym są opracowania graficzne. Analiza formy i treści tych opracowań obejmująca okres powojenny wykazała, że ulegały one zmianom, co wynikało zarówno ze zmian przepisów prawnych, jak i z rozwoju narzędzi oraz technologii stosowanych do ich sporządzania. Do czasu transformacji ustrojowej rysunki planistyczne wykonywane były ręcznie, według obowiązujących szczegółowych standardów określających zasady ich sporządzania, w tym ujednolicone oznaczenia w planach miejscowych. Rysunki późniejszego okresu cechuje duża dowolność zapisu graficznego, wynikająca z braku pełnych i precyzyjnych prawnych standardów ich sporządzania. Natomiast rozwój technologii przyczynia się do coraz wyższej jakości technicznej tych opracowań. Obecnie jesteśmy w okresie dynamicznego rozwoju technologii geoinformatycznych, w którym stosowanie narzędzi GIS do sporządzania rysunków planistycznych to już kwestia nie wyboru, ale konieczności. Dostępne obecnie programy pracujące w środowisku GIS pozwalają nie tylko na precyzyjne wykonanie rysunku planistycznego w określonym układzie współrzędnych, ale oferują wiele udogodnień ułatwiających wykonanie tych rysunków oraz ich publikację na geoportalach, a także wiele możliwości w zakresie pozyskiwania i analizowania danych przestrzennych.

Korzystanie z tych narzędzi mogłoby być jeszcze bardziej efektywne, gdyby zostały znormalizowane schematy służące do publikacji dokumentów planistycznych, schematy tworzenia danych przestrzennych wykorzystywanych i stosowanych w planowaniu przestrzennym oraz oznaczenia graficzne na rysunkach planistycznych.

\section{Bibliografia}

Bąkowski T., 2004, Ustawa o planowaniu i zagospodarowaniu przestrzennym. Komentarz, http://abc.online. wolterskluwer.pl (dostęp 17 grudnia 2018).

Chmielewski J.M., 2001, Teoria urbanistyki w projektowaniu i planowaniu miast, Oficyna Wydawnicza Politechniki Warszawskiej, Warszawa.

Dekret z dnia 2 kwietnia 1946 r. o planowym zagospodarowaniu przestrzennym kraju, Dz.U. z 1946 r. Nr 16, poz. 109.

Dyrektywa 2007/2/WE Parlamentu Europejskiego i Rady z dnia 14 marca 2007 r. ustanawiająca infrastrukturę informacji przestrzennej we Wspólnocie Europejskiej (INSPIRE).

Izdebski W., 2009, Wykłady z przedmiotu SIT, rok akademicki 2009/2010, http://www.izdebski.edu.pl/ wykladysit/wykladsit_01.pdf (dostęp 17 grudnia 2018).

Izdebski W., Malinowski Z., 2017, Analiza wptywu ustawy o IIP na proces publikacji $i$ tworzenia miejscowych planów zagospodarowania przestrzennego, „Zeszyty Naukowe UZ. Inżynieria Środowiska” 2017, nr 166(44).

Kaczmarek S., 2012, Kultura gospodarowania przestrzenią w mieście, „Studia Miejskie” t. 5.

Rozporządzenie Ministra Infrastruktury z dnia 26 sierpnia 2003 r. w sprawie wymaganego zakresu projektu miejscowego planu zagospodarowania przestrzennego, Dz.U. z 2003 r. Nr 164, poz. 1587. 
Rozporządzenie Ministra Infrastruktury z dnia 28 kwietnia 2004 r. w sprawie zakresu projektu studium uwarunkowań i kierunków zagospodarowania przestrzennego gminy, Dz.U. z 2004 r. Nr 118, poz. 1233.

Ustawa z dnia 31 stycznia 1961 r. o planowaniu przestrzennym, Dz.U. z 1975 r. Nr 11, poz. 67 z późn. zm.

Ustawa z dnia 12 lipca 1984 r. o planowaniu przestrzennym, Dz.U. z 1989 r. Nr 17, poz. 99 z późn. zm.

Ustawa z dnia 7 lipca 1994 r. o zagospodarowaniu przestrzennym, Dz.U z 1994 r. Nr 89, poz. 415 z późn. zm.

Ustawa z dnia 27 marca 2003 r. o planowaniu i zagospodarowaniu przestrzennym, Dz.U z 2018 r., poz. 1945.

Ustawa z dnia 4 marca 2010 r. o infrastrukturze informacji przestrzennej, Dz.U. z 2010 r. Nr 76, poz. 489 z późn. zm.

Wytyczne do opracowania planów przestrzennego gmin zagospodarowania gmin - załącznik 2 „Ujednolicone oznaczenia w planach miejscowych", Ministerstwo Administracji, Gospodarki Terenowej i Ochrony Środowiska - Ministerstwo Rolnictwa, Warszawa, sierpień 1978.

Zarządzenie Ministra Gospodarki Przestrzennej i Budownictwa z dnia 17 października 1988 r. w sprawie zasad sporządzania projektów założeń do miejscowych planów zagospodarowania przestrzennego, „Monitor Polski” 1988 r., nr 30, poz. 269.

Zarządzenie nr 27 Ministra Budownictwa i Przemysłu Materiałów Budowlanych z dnia 3 września 1968 r. w sprawie szczegółowych przepisów o sporządzaniu miejscowych planów zagospodarowania przestrzennego, „Dziennik Budownictwa” 1968, nr 12, poz. 62.

http://www.mir.gov.pl/rozwoj_regionalny/Polityka_przestrzenna/Strony/polityka_przestrzenna.aspx (dostęp 17 grudnia 2018).

https://encyklopedia.pwn.pl/haslo/planowanie-przestrzenne;3957954.html (dostęp 17 grudnia 2018).

https://sjp.pl/metadane (dostęp 19 grudnia 2018). 